\title{
Formação de profissionais da educação: Visão crítica e perspectiva de mudança
}

\author{
José Carlos Libâneo * \\ Selma Garrido Pimenta**
}

RESUMO: O artigo apresenta breve análise crítica do histórico da formação dos profissionais da educação no Brasil, explicitando as ambigüidades do curso de pedagogia desde sua criação até a atualidade, o percurso dos cursos de formação de professores e o impacto dos debates promovidos em instituições, entidades e movimentos em torno da questão. Na seqüência, o texto analisa a natureza e a identidade da pedagogia como área de conhecimento do campo educacional e as questões relacionadas com o exercício profissional dos pedagogos e dos professores. Indica, finalmente, sugestões de organização institucional e de possíveis percursos de formação desses profissionais que apontam para uma mudança do quadro atual. ${ }^{1}$

Palavras-chave: Pedagogia, teoria pedagógica, formação de profissionais da educação, formação pedagógica, formação docente

Introdução

Há cerca de 20 anos, por iniciativa de movimentos de educadores e, em paralelo, no âmbito do Ministério da Educação, iniciava-se um debate nacional sobre a formação de pedagogos e professores, com base na críti-

\footnotetext{
*Professor titular da Universidade Católica de Goiás. Email: libaneo@rural.com.br

** Professora titular da Faculdade de Educação da Universidade de São Paulo.
} 
ca da legislação vigente e na realidade constatada nas instituições formadoras. O marco histórico de detonação do movimento pela reformulação dos cursos de formação do educador foi a I Conferência Brasileira de Educação realizada em São Paulo em 1980, abrindo-se o debate nacional sobre o curso de pedagogia e os cursos de licenciatura. A trajetória desse movimento destaca-se pela densidade das discussões e pelo êxito na mobilização dos educadores, mas o resultado prático foi modesto, não se tendo chegado até hoje a uma solução razoável para os problemas da formação dos educadores, nem no âmbito oficial nem no âmbito das instituições universitárias.

A discussão sobre a identidade do curso de pedagogia, que remonta aos pareceres de Valnir Chagas na condição de membro do antigo Conselho Federal de Educação, é retomada nos encontros do Comitê Nacional Pró-formação do Educador, mais tarde transformada em Associação Nacional pela Formação dos Profissionais da Educação, e é bastante recorrente para pesquisadores da área. Estes já apontavam, em meados dos anos 80 , a necessidade de se superar a fragmentação das habilitações no espaço escolar, propondo a superação das habilitações e especializações pela valorização do pedagogo escolar:

(...) a posição que temos assumido é a de que a escola pública necessita de um profissional denominado pedagogo, pois entendemos que o fazer pedagógico, que ultrapassa a sala de aula e a determina, configura-se como essencial na busca de novas formas de organizar a escola para que esta seja efetivamente democrática. A tentativa que temos feito é a de avançar da defesa corporativista dos especialistas para a necessidade política do pedagogo, no processo de democratização da escolaridade. (Pimenta 1988)

O curso de pedagogia - sem entrar agora no mérito de sua função, isto é, de formar professores ou especialistas ou ambos - pouco se alterou em relação à Resolução $n^{\circ}$ 252/69. Experiências alternativas foram tentadas em algumas instituições e o antigo CFE expediu alguns pareceres sobre "currículos experimentais", mas nenhum deles, a rigor, apresenta algo realmente inovador. Possíveis "novidades" no chamado "curso de pedagogia" seriam, por exemplo, a atribuição, ao lado de outras, da formação em nível superior de professores para as séries iniciais do Ensino Fundamental, supressão das habilitações (administração escolar, orientação educacional, supervisão escolar etc.) e alterações na denominação de al- 
gumas disciplinas. Alterações geralmente inócuas, pois na maior parte dos casos foi mantida a prática da grade curricular e os mesmos conteúdos das antigas disciplinas, por exemplo, Organização do trabalho pedagógico manteve o conteúdo da anterior Administração escolar.

Em relação aos cursos de licenciatura, também não houve nenhuma mudança substantiva desde a Resolução $n^{\circ}$ 292/62 do CFE, que dispunha sobre as matérias pedagógicas para a licenciatura. $\mathrm{O}$ que se tentou foram diferentes formas de organização do percurso da formação, umas mantendo o 3+1 já presente em 1939, outras distribuindo as disciplinas pedagógicas ao longo do curso específico. Quanto ao local da formação pedagógica, em alguns lugares ela foi mantida nas faculdades de educação, em outros, foi deslocada, total ou parcialmente, aos institutos/departamentos/cursos.

Atualmente, a atuação do Ministério da Educação e do CNE na regulamentação da LDB nº 9.394/96 tem provocado a mobilização dos educadores de todos os níveis de ensino para rediscutir a formação de profissionais da educação. A nosso ver, não bastam iniciativas de formulação de reformas curriculares, princípios norteadores de formação, novas competências profissionais, novos eixos curriculares, base comum nacional etc. Faz-se necessária e urgente a definição explícita de uma estrutura organizacional para um sistema nacional de formação de profissionais da educação, incluindo a definição dos locais institucionais do processo formativo. Na verdade, reivindicamos o ordenamento legal e funcional de todo o conteúdo do Titulo VI da nova LDB.

Resumidamente, o disposto no Titulo VI da nova LDB é o seguinte:

a) Cursos de licenciatura plena para formar professores de educação básica, em universidades e Institutos Superiores de Educação:

- $\quad$ Curso Normal Superior (licenciatura para formar docentes de educação infantil e séries iniciais do Ensino Fundamental) e licenciaturas para formar professores de $5^{\mathrm{a}}$ a $8^{\mathrm{a}}$ e Ensino Médio);

- $\quad$ programas de formação pedagógica para portadores de diplomas de educação superior;

- programas de educação continuada.

b) Cursos de graduação e pós-graduação em pedagogia para formar profissionais da educação para administração, planejamento, inspeção, supervisão e orientação educacional.

c) Cursos de preparação para o magistério de Ensino Superior. 
Pelo Edital $n^{\circ} 4$, de 3/12/97, a SESu/MEC designou comissões de especialistas para elaboração de diretrizes curriculares dos cursos superiores, incluindo as licenciaturas onde coubesse. Em 6/5/99, a Comissão de Especialistas de ensino de Pedagogia (designada pela Portaria SESu/MEC no 146, de março de 1998) tornou pública sua proposta de diretrizes curriculares para o curso de pedagogia. O mesmo órgão, por meio da Portaria $n^{\circ} 808$, de 8/6/99, designou um Grupo de Trabalho para elaboração das diretrizes curriculares para todas as licenciaturas, reconhecendo a necessidade de orientações normativas gerais para a parte curricular referente à formação pedagógica. Os debates ocorridos nesse GT resultaram no Documento Norteador para a Elaboração de Diretrizes Curriculares para os Cursos de Formação de Professores (1999), já encaminhado à SESu. Todavia, foram manifestadas nas reuniões de trabalho diferentes posições sobre a formação dos profissionais da educação, não incluídas no corpo do referido documento. O objetivo deste texto é apresentar uma dessas posições, que expressa a proposta de um sistema nacional de formação dos profissionais da educação.

A proposta básica é a de que a formação dos profissionais da educação para atuação na educação básica far-se-á, predominantemente, nas atuais faculdades de educação, que oferecerão curso de pedagogia, cursos de formação de professores para toda a educação básica, programa especial de formação pedagógica, programas de educação continuada e de pós-graduação. As faculdades de educação terão sob sua responsabilidade a formulação e a coordenação de políticas e planos de formação de professores, em articulação com as pró-reitorias ou vice-reitorias de graduação das universidades ou órgãos similares nas demais Instituições de Ensino Superior, com os institutos/faculdades/departamentos das áreas específicas e com as redes pública e privada de ensino.

O curso de pedagogia destinar-se-á à formação de profissionais interessados em estudos do campo teórico-investigativo da educação e no exercício técnico-profissional como pedagogos no sistema de ensino, nas escolas e em outras instituições educacionais, inclusive as não-escolares.

Os cursos de formação de professores e os programas mencionados, abrangendo todos os níveis da educação básica, serão realizados num Centro de Formação, Pesquisa e Desenvolvimento Profissional de Professores - CFPD, que integrará a estrutura organizacional das faculdades de educação e destinar-se-á à formação de professores para a educação básica, da educação infantil ao Ensino Médio. 


\section{Distinguindo o curso de pedagogia ( stricto sensu) e o curso de formação de professores para as séries iniciais do Ensino Fundamental ${ }^{2}$}

Tornou-se lugar-comum no discurso de educadores, especialmente os que atuam em faculdades de educação, a identificação dos cursos de pedagogia com os cursos de formação de professores das séries iniciais do Ensino Fundamental, ainda que boa parte deles também se destine a formar docentes para as disciplinas pedagógicas da habilitação ao magistério em nível de $2^{\circ}$ grau.

Para tornar essa problemática mais clara convém, primeiramente, rememorar as ambigüidades que vem acompanhando o curso de pedagogia e cursos de licenciatura. ${ }^{3}$ Quando foi criado o curso de pedagogia, em 1939, ele se destinava a formar bacharéis (técnicos de educação) e licenciados em pedagogia, inaugurando o que veio a denominar-se esquema $3+1$, com blocos separados para o bacharelado e a licenciatura. Os professores dos antigos primário e pré-primário eram formados em Curso Normal nos institutos de educação, ao passo que o professores para os antigos cursos ginasial e colegial eram formados nas faculdades de Filosofia, Ciências e Letras.

O Parecer $n^{\circ}$ 251/62 estabelece para o curso de pedagogia o encargo de formar professores para os cursos normais e "profissionais destinados às funções não-docentes do setor educacional", os técnicos de educação ou especialistas de educação", e anuncia a possibilidade de, no futuro, formar o "mestre primário em nível superior". Nesse mesmo ano, o Parecer $n^{0}$ 292/62 fixa as matérias pedagógicas dos cursos de licenciatura para o magistério em escolas de nível médio (ginasial e colegial), mantendo, na prática, a separação entre bacharelado e licenciatura ou, ao menos, as disciplinas "de conteúdo" e as disciplinas "pedagógicas". Embora algumas análises apontem para a impropriedade de formar, nessa época, técnicos de educação para um campo de trabalho inexistente, talvez o que tenha faltado fosse a regulamentação da profissão de pedagogo. ${ }^{4}$

O Parecer $n^{\circ} 252$, de 1969, definiu a estrutura curricular do curso de pedagogia que vigorou até pouco tempo atrás, com a promulgação da LDB de 1996. A resolução normativa que acompanha o parecer estabelece com mais precisão a função desse curso: formar professores para o ensino Normal e especialistas para as atividades de orientação, administração, super- 
visão e inspeção no âmbito das escolas e dos sistemas escolares. Permite também ao licenciado exercer o magistério nas séries iniciais, dentro da habilitação para o ensino Normal (isto é, não se previu uma habilitação específica para se lecionar nas séries iniciais). O currículo mínimo compreendia uma parte comum a todas as habilitações e outra diversificada, em função da habilitação específica escolhida pelo aluno. A lista de habilitações incluía, pelo menos, oito tipos de atividades, em função das quais se ofereciam as opções curriculares. ${ }^{5}$ Consolidava-se, assim, a idéia de formação específica de técnicos em educação, definindo o exercício profissional do pedagogo não-docente. Uma das justificativas para a oferta das habilitações (administração escolar, supervisão escolar, ${ }^{6}$ orientação educacional, entre outras) e para a profissionalização do pedagogo era a ampliação do atendimento às necessidades de escolarização básica, que tinha um forte apelo na política educacional da época.

O Parecer $n^{\circ}$ 252, justamente por explicitar melhor a natureza de um curso de pedagogia - e, não por acaso, no contexto da ditadura militar - recebeu inúmeras críticas no final da década de 1970 e no período seguinte. O conteúdo dessas críticas é amplamente conhecido e não precisa ser reproduzido aqui. Em virtude das finalidades e dos limites deste texto, queremos apenas destacar algumas delas.

A crítica de que o curso de pedagogia de 1969 era "tecnicista" parece pertinente, a levar em conta o discurso oficial da época. Essa crítica é sintetizada por Silva (1999) nos seguintes termos:

Com a aprovação da (...) Lei da Reforma Universitária, triunfam os princípios de racionalidade, eficiência e produtividade no trato do Ensino Superior. A tradição liberal de nossa universidade fica interrompida e nasce o que alguns irão passar a chamar de universidade tecnocrática, ainda que mesclada de nuanças do pensamento liberal.

A esses aspectos foram agregadas as críticas à fragmentação da formação do pedagogo, à divisão técnica do trabalho na escola, à separação entre teoria e prática, à separação entre o pedagogo especialista e o trabalho docente. ${ }^{7}$

Não nos parece problemática hoje a ênfase que o Parecer deu à necessidade de se formarem técnicos de educação nem ao reconhecimento de tarefas específicas a serem realizadas nas escolas para acom- 
panhamento do ensino. Sem deixar de reconhecer que, de fato, houve uma fragmentação muito grande das tarefas, isso não poderia ter comprometido a existência de especialistas na escola. A nosso ver, a divisão de funções corresponde a uma lógica da organização escolar e, mais ainda, essas funções implicariam uma formação específica, dada a complexidade envolvida no desempenho dessas funções. Dessa forma, o que nos parecem problemáticos são os seguintes aspectos: a) o caráter "tecnicista" do curso e o conseqüente esvaziamento teórico da formação, excluindo o caráter da pedagogia como investigação do fenômeno educativo; b) o agigantamento da estrutura curricular que leva ao mesmo tempo a um currículo fragmentado e aligeirado; c) a fragmentação excessiva de tarefas no âmbito das escolas; d) a separação no currículo entre os dois blocos, a formação pedagógica de base e os estudos correspondentes às habilitações. ${ }^{8}$

A questão mais relevante, todavia, é o esvaziamento dos estudos sistemáticos de educação e a descaracterização profissional do pedagogo. Quanto ao esvaziamento da teoria pedagógica, Pimenta (1998) faz a seguinte constatação:

(...) há um contingente maciço de egressos dos cursos de pedagogia que, curiosamente, não estudaram pedagogia (sua teoria e sua prática), pois esses cursos, de modo geral, oferecem estudos disciplinares das ciências da educação que, na maioria das vezes, ao partirem dos campos disciplinares das ciências-mãe para falar sobre educação, o fazem sem dar conta da especificidade do fenômeno educativo e, tampouco, sem tomá-lo nas suas realidades histórico-sociais e na sua multiplicidade - o que apontaria para uma perspectiva interdisciplinar e multirreferencial.

Quanto à descaracterização profissional do pedagogo, subsumido ao "professor", sua formação passa a ser dominada pelos estudos disciplinares das áreas das metodologias. Estas, ao voltarem seus estudos diretamente à sala de aula, espaço fundamental da docência, ignoram os determinantes institucionais, históricos e sociais (objeto de estudo da pedagogia). Desse modo, a pedagogia, ciência que tem a prática social da educação como objeto de investigação e de exercício profissional - no qual se inclui a docência, embora nele se incluam outras atividades de educar - não tem sido tematizada nos cursos de formação de pedagogos (cf. Pimenta 1998). 
Por essas razões, por volta dos anos 1983-84, com base na crítica à fragmentação e à divisão técnica do trabalho na escola, algumas faculdades de educação suprimiram do currículo as habilitações, passando a ter apenas duas habilitações - professor das séries iniciais do $1^{\circ}$ grau e professor de cursos de habilitação ao magistério -, descartando boa parte da fundamentação pedagógica do curso. Fora das faculdades, em decorrência dessas mudanças curriculares e da difusão das propostas do movimento pela reformulação da formação do educador, as Secretarias de Educação retiraram das escolas ou deixaram de contratar profissionais pedagogos, prejudicando o atendimento pedagógico-didático às escolas e comprometendo o exercício profissional do pedagogo. Além disso, com a descaracterização dos pedagogos-especialistas como profissionais, as associações de pedagogos (por exemplo, Associação Nacional de Orientadores Educacionais, Associação Nacional de Supervisores Educacionais) se autodissolveram, resultando na perda do espaço de discussão teórico-prática da pedagogia e do exercício profissional do pedagogo existente nessas associações.

Essa análise mostra como se chegou a uma descentralidade do enfoque da pedagogia como estudo da ciência da educação. Entretanto, não se pode dizer que a desvalorização social e acadêmica desse campo de conhecimentos tenha sido resultado apenas da legislação tecnicista do período 1962-80 e do movimento pela reformulação dos cursos de formação do educador. ${ }^{9} \mathrm{Na}$ verdade, já nos anos 20 , com o movimento da Educação Nova, os estudos pedagógicos sistemáticos começaram a perder espaço, com base em um reducionismo psicológico. A pedagogia vai adquirindo a conotação de operacionalização metodológica do ensino, com base no que se propõe a formação dos técnicos de educação e a formação de professores, consolidando o privilégio das dimensões metodológica e organizacional em detrimento das dimensões filosófica, epistemológica e científica. Sobre isso escreveu Libâneo (1998):

Ainda que o Parecer 252/69 mantenha a denominação "curso de pedagogia", seu conteúdo deixa entrever que o termo "pedagógico" tem o sentido de metodológico, técnico, administrativo, no mesmo tom da linguagem dos "profissionais da educação" da década de 20. Além disso, pesa-lhe a herança do passado em que estudos pedagógicos referem-se quase sempre à preparação de professores, o que explica, ainda hoje, em algumas faculdades de educação, a identificação do termo "pedagogia" com a formação 
de professores para as séries iniciais do Ensino Fundamental, com o que a pedagogia tende a reduzir-se à prática do ensino.

A tendência que parece ser dominante hoje entre os educadores - ao menos no que diz respeito aos seguidores das propostas mais recentes da Anfope - é esta: o curso de pedagogia destina-se à formação do professor de $1^{a}$ a $4^{\text {a }}$ (que muitos chamam de professor normalista de nível superior). Ou seja, acabou aquele curso de pedagogia concebido em 1939 e parcialmente mantido em 1962 e $1969 .{ }^{10}$ Como se sabe, aquelas propostas giram em torno do lema: a formação de todo educador deve ter como base a docência. A defesa desse lema e as propostas de formação que dele decorrem têm dificultado uma discussão mais aberta da questão, colocando o debate na contramão das necessárias mudanças na formação de professores. A nosso ver, as propostas atuais da Anfope trazem como conseqüências:

- a identificação de estudos sistemáticos de pedagogia com a licenciatura (formação de professores para as séries iniciais do Ensino Fundamental) e, por conseguinte, redução da formação de qualquer tipo de educador à formação do docente;

- a descaracterização do campo teórico-investigativo da pedagogia e das ciências da educação, eliminando da universidade os estudos sistemáticos do campo científico da educação e a possibilidade de pesquisa específica e de exercício profissional do pedagogo; o que leva ao esvaziamento da teoria pedagógica, acentuando o desprestígio acadêmico da pedagogia como campo cientifico;

- $\quad$ eliminação/descaracterização do processo de formação do especialista em pedagogia (pedagogo stricto sensu), subsumindo o especialista (diretor de escola, coordenador pedagógico, planejador educacional, pesquisador em educação etc.) no docente;

- identificação entre o campo epistemológico e o campo profissional, como se as dificuldades naquele campo levassem ipso facto à crise do outro;

- $\quad$ segregação do processo de formação de professores da $1^{a}$ à $4^{a}$ em relação às demais licenciaturas. 
O documento ora concluído pela Comissão de Especialistas de ensino de pedagogia - Diretrizes Curriculares para o curso de Pedagogia reforça esses problemas. Com efeito, o documento define o pedagogo como:

Profissional habilitado a atuar no ensino, na organização e na gestão de sistemas, unidades e projetos educacionais e na produção e difusão do conhecimento, em diversas áreas da educação, tendo a docência como base obrigatória de sua formação e identidade profissionais.

Define como áreas de atuação profissional: a docência na educação infantil, nas séries iniciais do Ensino Fundamental e nas disciplinas da formação pedagógica do nível médio, podendo atuar, ainda, na organização de sistemas, unidades, projetos de experiências educacionais escolares e não escolares; na produção e difusão do conhecimento cientifico e tecnológico do campo educacional; nas áreas emergentes do campo educacional.

Como se vê, nada muito diferente do que sempre existiu na legislação anterior, a não ser o destaque que se dá à formação de professores de educação infantil e das séries iniciais do $1^{\circ}$ grau (já prevista no Parecer 252/69). O documento não utiliza o termo "habilitações" (embora refira-se ao pedagogo como profissional "habilitado"), mas menciona a diversificação na formação do pedagogo para atender às diferentes demandas sociais por intermédio da "formação diferenciada, composta pelas diferentes opções oferecidas aos alunos". Ou seja, são previstas áreas de atuação do pedagogo não-docente (outras habilitações?), tendo a docência como base comum da formação.

Verifica-se que a proposta de diretrizes curriculares para o curso de pedagogia, tal como aparece no documento da Comissão de Especialistas, reincide nos mesmos problemas já tão criticados: o "inchaço" do currículo, pretensões ambiciosas quanto à diversidade de profissionais a serem formados, aligeiramento da formação (dada a impossibilidade real, no percurso curricular, de conciliar formação de profissionais docentes e não-docentes), empobrecimento na oferta de disciplinas (já que, para atender ao menos seis das áreas de atuação previstas, será necessário reduzir o número de disciplinas, a fim de respeitar o total de $3.200 \mathrm{~h}$ 
do curso). Além do mais, fica evidente a impossibilidade de se dar ao curso o caráter de aprofundamento da ciência da educação para formar o pesquisador e o especialista em educação.

\section{Por que discordamos das posições defendidas hoje pela Anfope e da proposta de diretrizes curriculares da Comissão de Especialistas}

Há temas de grande relevância na pauta de discussões da Anfope, como a exigência de formação em nível superior dos professores da $1^{\frac{a}{a}}$ à $4^{\mathrm{a}}$ série, a valorização profissional do professor, a postulação da base comum nacional, a gestão democrática na escola. Todavia, temos discordâncias bastante explícitas em relação à tese principal defendida atualmente por essa entidade - a docência como base da formação de todo educador.

Com efeito, o princípio que se tornou o lema e o apelo político da Anfope é conhecido: a docência constitui a base da identidade profissional de todo educador, todos os cursos de formação do educador deverão ter uma base comum: são todos professores. Conforme já afirmamos, esse princípio levou à redução da formação do pedagogo à docência, à supressão em alguns lugares da formação de especialistas (ou do pedagogo não diretamente docente), ao esvaziamento da teoria pedagógica em virtude da descaracterização do campo teórico-investigativo da pedagogia e das demais ciências da educação, à retirada da universidade dos estudos sistemáticos do campo científico da educação e, em conseqüência, da formação do pedagogo para a pesquisa específica na área e para o exercício profissional.

Certamente não estamos sozinhos, ao menos em relação aos estudiosos que não gravitam no âmbito de influência da Anfope, ao afirmar que as modificações curriculares decorrentes das teses do movimento de reformulação dos cursos de formação dos profissionais da educação acabaram por comprometer características positivas do curso de pedagogia regido pela Resolução CFE n 252/69. A sobrecarga no currículo de disciplinas ligadas à formação de professores das séries iniciais do antigo $1^{\circ} \mathrm{grau}$ levou à diminuição do peso das disciplinas teóricas (fundamentos da educação, currículo, avaliação, teorias da educação) e, especificamente, das disciplinas que identificavam mais o exercício profissional do pedagogo. Muitos pedagogos se perguntam hoje: onde estão os especialistas de planejamento da educação, de administração de sistemas, gestão escolar, formulação de políticas públicas para a educação, avaliação educacional e 
avaliação da aprendizagem, pesquisa pedagógica específica etc.? Os atuais cursos estão formando profissionais competentes nessas áreas? É viável formar num mesmo curso, com duração de quatro anos, o professor profissionalmente competente de $1^{\underline{a}}$ a $4^{a}$ série e, ao mesmo tempo, o pedagogo stricto sensu, também profissionalmente competente naqueles campos profissionais mencionados? Essas perguntas podem ser dirigidas tanto à Anfope quanto à Comissão de Especialistas da pedagogia que, grosso modo, encamparam as teses da Anfope.

Nosso entendimento é de que a tese da identificação do curso de pedagogia com a formação de professores - ou seja, uma licenciatura - foi gestada em razão de circunstâncias históricas peculiares da história da educação deste país. ${ }^{11}$ Os legisladores, em todos esses anos desde 1939, tentaram equacionar a formação do pedagogo stricto sensu e a formação de professores num curso só, o curso de pedagogia, mas que, na verdade, teria como suporte a formação de professores para as séries iniciais do sistema de ensino. Após a legislação de 1962 e 1969, o conselheiro Valnir Chagas, que deixou sua marca no pensamento sobre formação de professores nesse período, formulou a indicação $\mathrm{n}^{0} \mathbf{7 0 / 7 6}$ sobre a preparação em nível de graduação dos especialistas em educação. Para justificar sua nova proposta, Chagas afirma: "O caminho é sempre o mesmo, de restabelecer em novo plano a linha tradicional, hoje tão nítida como há um século, e habilitar o especialista no professor". O raciocínio inscrito no mencionado parecer deixa entrever a identificação do termo pedagógico com o termo metodológico, e da expressão formação pedagógica com formação docente. Entendemos, assim, que a tese de que a formação de todo educador deve ter por base a docência precisa ser entendida dentro de posicionamentos localizados de intelectuais, em momentos históricos específicos da educação brasileira. Com isso queremos dizer que tudo o que é histórico é mutável e que conquistas históricas, por mais aguerridas que tenham sido, não podem ser cristalizadas. A redução do trabalho pedagógico à docência não pode, portanto, constituir-se em algo imutável. Nem mesmo chega a ser uma questão de cunho epistemológico ou conceitual. As novas realidades estão exigindo um entendimento ampliado das práticas educativas e, por conseqüência, da pedagogia. Além disso, no mundo inteiro existem cursos específicos de pedagogia (em alguns lugares denominados "ciências da educação") distintos dos cursos de formação de professores.

O desdobramento das vicissitudes do curso de pedagogia nestes últimos 20 anos pode ser explicado a partir de fatos notórios. O Brasil viveu 21 anos de ditadura militar, cujo impacto político e social afetou vários cam- 
pos, mormente o da educação. A contestação do regime se fazia necessária, e contra ele mobilizaram-se muitos militantes políticos, profissionais, intelectuais, organizações de esquerda. A grande luta nesses anos precisou ser muito mais política do que técnica, a fim de desenvolver a consciência política das pessoas, criar espaços democráticos, incentivar a prática de assembléias, reuniões, movimentos e desenvolver formas participativas de gestão. Ora, os que ocupavam esses espaços eram sobretudo os sociólogos, filósofos e militantes políticos. Também os pedagogos se engajaram na resistência à ditadura militar. No entanto, muitos deles deixaram de lado seu trabalho específico - ligado aos aspectos internos das práticas escolares e dos processos de ensino e aprendizagem -, incorporando o discurso sociológico, mas distanciando-se da problemática teórico-prática de sua área. Não que os pedagogos não devessem ter um ideário político e se alinhar aos demais intelectuais na luta política maior. O problema foi o fato de muitos deles não terem compreendido que a própria ação pedagógica dentro das escolas e das salas de aula era também uma prática política, sem prejuízo da sua inserção nas lutas políticas mais amplas.

A nosso ver, a abordagem sociologizada da formação do educador, assumida pelo movimento pela formação de educadores, gerou uma visão "militante" do profissional da educação. De acordo com essa abordagem, bastaria ao professor ter uma visão política, globalizante, das relações entre educação e sociedade, compromisso político etc., que o resto viria por acréscimo. É verdade que essa ênfase no compromisso político correspondia às características daquele momento histórico, mas é necessário reconhecer que esse empenho na construção de um projeto nacional democrático precisava ter correspondência com práticas pedagógico-didáticas, curriculares, no interior do processo de ensino e aprendizagem, nas práticas de ensino. Foi um grande equívoco dissolver o específico da prática educativa nas salas de aula (a aprendizagem, o crescimento cognitivo dos alunos etc.) na prática política. Faltou entender que um trabalho bem feito com as crianças no interior das salas de aula também é um ato político, e dos mais nobres. O discurso especificamente pedagógico foi, assim, afastado das discussões, e em alguns casos chegou a ser rechaçado, em decorrência do preconceito que sempre se alimentou contra a pedagogia como campo de conhecimento e contra os pedagogos de profissão. Na prática, essa tendência resultou, em vários lugares, na negação explícita do campo próprio de estudos da pedagogia (e por decorrência, da didática). É em boa parte por isso que a licenciatura para a formação de professores de $1^{\underline{a}}$ a $4^{\underline{a}}$ passou a ser chamada inadequadamente de pedagogia. 
Para além de razões históricas, pensamos que a identificação do pedagogo com o docente incorre num equívoco lógico-conceitual. A pedagogia é uma reflexão teórica baseada nas práticas educativas e sobre elas. Investiga os objetivos sociopolíticos e os meios organizacionais e metodológicos de viabilizar os processos formativos em contextos socioculturais específicos. Todo educador sabe, hoje, que as práticas educativas ocorrem em muitos lugares, em muitas instâncias formais, não-formais, informais. Elas acontecem nas famílias, nos locais de trabalho, na cidade e na rua, nos meios de comunicação e, também, nas escolas. Não é possível mais afirmar que o trabalho pedagógico se reduz ao trabalho docente nas escolas. A ação pedagógica não se resume a ações docentes, de modo que, se todo trabalho docente é trabalho pedagógico, nem todo trabalho pedagógico é trabalho docente. Por exemplo, o MST faz um trabalho pedagógico mas não necessariamente um trabalho docente, a não ser quando reúne suas crianças nas salas de aula para a escolarização formal ou os militantes para estudar o aprimoramento de práticas agrícolas, os direitos trabalhistas de lavradores etc.). O pedagógico e o docente são termos inter-relacionados mas conceitualmente distintos. Portanto, reduzir a ação pedagógica à docência é produzir um reducionismo conceitual, um estreitamento do conceito de pedagogia. A não ser que os defensores da identificação pedagogia-docência entendam o termo pedagogia como metodologia, isto é, como procedimentos de ensino, prática do ensino, que é o entendimento vulgarizado do termo. Mas pensar assim significa desconhecer os conceitos mais elementares da teoria educacional. A pedagogia é mais ampla que a docência, educação abrange outras instâncias além da sala de aula, profissional da educação é uma expressão mais ampla que profissional da docência, sem pretender com isso diminuir a importância da docência. E não existe suporte teórico, conceitual, para justificar essa idéia de "docência ampliada", argumento usado por muitos colegas para justificar essa identificação reducionista de faculdade de educação com formação de professores.

É claro que esse reducionismo, descaracterizando a pedagogia como campo teórico-investigativo e identificando-a com uma licenciatura, teve conseqüências na discussão sobre o papel das faculdades de educação. Muitos não aceitam essa ligação, mas creio que nossa argumentação ajuda a entender a questão. Uma vez dispensadas as habilitações e reduzindo-se o papel das faculdades de educação a proporcionar licenciatura para formar professores para as séries iniciais e para o curso Normal, não se teria mais o curso de pedagogia (stricto sensu). Ou seja, já não teria sentido a existência das faculdades de educação, bastando 
transformá-las em centros de formação de professores. Não estaria aí a origem da criação dos Institutos Superiores de Educação?

A proposta de curso de pedagogia (diferenciado do curso de licenciatura para formação de professores de $1^{\frac{a}{a}}$ a $4^{a}$ ) atribui a denominação "pedagogia" ao campo teórico-investigativo da educação (em conexão com as demais ciências da educação) e ao campo técnico-profissional de formação do profissional não diretamente docente, e de "pedagogo" ao profissional formado nesse curso. Dissolve-se, assim, a designação "pedagogia" para identificar o curso de formação de professores para as séries iniciais do Ensino Fundamental, postulando-se a regulamentação do curso de pedagogia destinado a oferecer formação teórica, científica e técnica para interessados em aprofundamento na teoria pedagógica, na pesquisa pedagógica e no exercício de atividades pedagógicas específicas - planejamento de políticas educacionais, gestão do sistema de ensino e das escolas, formação de professores, assistência pedagógico-didática a professores e alunos, avaliação educacional, pedagogia empresarial, animação cultural, produção e comunicação nas mídias, movimentos sociais e outros campos de atividade educacional, inclusive as não-escolares. A nosso ver, a ruptura da herança da identificação de um currículo de estudos sistemáticos de pedagogia com um currículo de licenciatura para formar professores para as séries iniciais do Ensino Fundamental corrige o esvaziamento da teoria pedagógica no Brasil, decorrente da histórica ambigüidade produzida pelos legisladores, desde o final dos anos 30 até hoje, entre a formação do pedagogo stricto sensu e a formação do professor das séries iniciais do Ensino Fundamental. ${ }^{12}$

Desejamos destacar a importância da formação de profissionais da educação para atuar em contextos não-escolares. É acentuada a consciência atual da importância e da necessidade da intervenção participante e eficaz desses profissionais no âmbito das práticas socioculturais, tendo em vista que processos pedagógicos informais estão sempre implícitos nas práticas, efetivadas no plano coletivo e comunitário. Assim, tanto nas iniciativas de programas de educação popular, dirigidos aos mais heterogêneos segmentos da população não formalmente escolarizada, quanto nas propostas de intervenção pedagógica nas atividades de cunho cultural, desenvolvidas pelos novos e sofisticados meios de comunicação de massa, passando pela necessária liderança nos diversos movimentos sociais, a presença e a participação de profissionais da educação se fazem relevantes e imprescindíveis. Até hoje pouco se cuidou 
da preparação formal e sistematizada de agentes e lideranças culturais que se especializassem no exercício de funções pedagógicas nesses ambientes não-escolares, levando-se em conta sua importância como mediadores da educabilidade, necessária e capilarmente presente mesmo no processo informal de consolidação de uma cultura que seja articulada com uma proposta de construção da cidadania. Assim, reivindica-se, com toda a legitimidade, a presença atuante de profissionais dotados de capacitação pedagógica para atuarem nas mais diversas instituições e ambientes da comunidade: nos movimentos sociais, nos meios de comunicação de massa, nas empresas, nos hospitais, nos presídios, nos projetos culturais e nos programas comunitários de melhoria da qualidade de vida. Essa participação pedagógica também exige preparação prévia, sistemática e qualificada (cf. Severino 1999).

Reiteramos, pois, o entendimento de que os profissionais da educação formados pelo curso de pedagogia atuarão nos vários campos sociais da educação, decorrentes de novas necessidades e demandas sociais a serem reguladas profissionalmente. Tais campos são: as escolas e os sistemas escolares; os movimentos sociais; as diversas mídias, incluindo o campo editorial; a área da saúde; as empresas; os sindicatos e outros que se fizerem necessários. Em todos esses campos de exercício profissional, desenvolverá funções de gestão e formulação de políticas educacionais; organização e gestão de sistemas e de unidades escolares; de projetos e experiências educacionais; de planejamento, coordenação, execução e avaliação de programas e projetos educacionais, relativos às diferentes faixas etárias (criança, jovens, adultos, terceira idade); na produção e difusão do conhecimento científico e tecnológico do campo educacional e outras.

\section{A favor de um curso específico de pedagogia}

Conforme vimos considerando, as faculdades de educação sediariam, de forma articulada, o curso de pedagogia e a formação inicial e continuada de professores. O que é esse curso de pedagogia? Trata-se de curso para a realização da investigação em estudos pedagógicos, tomando a pedagogia como campo teórico e como campo de atuação profissional. Como campo teórico, destina-se à formação de profissionais que desejem aprimorar a reflexão e a pesquisa sobre a educação e o ensino da 
pedagogia, propriamente dita. Como campo de atuação profissional, destina-se à preparação de pesquisadores, planejadores, especialistas em avaliação, gestores do sistema e da escola, coordenadores pedagógicos ou de ensino, comunicadores especializados para atividades escolares e extraescolares, animadores culturais, de especialistas em educação a distância, de educadores de adultos no campo da formação continuada etc.

A ampliação do campo educacional e, por conseqüência, da atuação pedagógica é uma realidade constatada por muitos autores. Já argumentamos anteriormente sobre a idéia de que a atividade pedagógica perpassa, hoje, toda a sociedade, extrapolando o âmbito escolar formal, abrangendo esferas mais amplas de educação informal e não-formal. Não faz sentido, pois, o reducionismo da ação pedagógica à docência, ainda que esta seja também uma genuína prática pedagógica.

O curso de pedagogia proposto tem correlatos em praticamente todos os países do mundo, embora em alguns lugares, especialmente na Europa, receba a designação de "ciências da educação". Poder-se-ia perguntar: por que não chamar esse curso de ciências da educação e não de pedagogia? Libâneo aponta, em publicação recente (1998), quatro posições a respeito desse assunto e sobre a denominação "ciências da educação" escreve:

\begin{abstract}
(..) tal denominação (...) é criticada por provocar dispersão no estudo da problemática educativa, levando a uma postura pluridisciplinar ao invés de interdisciplinar. Ou seja, a autonomia dada a cada uma das ciências da educação levaria a enfoques parciais da realidade educativa, comprometendo a unidade temática e abrindo espaço para os vários reducionismos (sociológico, psicológico, econômico...), como aliás a experiência brasileira tem confirmado.
\end{abstract}

Em concordância com vários autores (entre outros, Sarramona e Marques 1985, Vilsaberghi 1983, Estrela 1992), Libâneo assume que a pedagogia se apóia nas ciências da educação, mas não perde com isso sua autonomia epistemológica e não se reduz ao campo conceitual de uma ou outra, nem ao conjunto dessas ciências.

A pluridimensionalidade do fenômeno educativo não elimina sua unicidade, que permite "estabelecer um corpo cientifico que tem o 
fenômeno educativo em seu conjunto como objeto de estudo, com a finalidade expressa de dar coerência à multiplicidade de ações parcializadas" (Sarramona e Marques 1985). Nessa concepção, a pedagogia promove a síntese integradora dos diferentes processos analíticos que correspondem a cada uma das ciências da educação em seu objeto específico de estudo.

Também Pimenta (1996) discute detidamente a questão recorrendo a vários autores, argumentando pela necessidade de a pedagogia postular sua especificidade epistemológica, de modo a não se conformar com uma mera posição de campo aplicado de outras ciências que também estudam a educação. Com base nisso, firma sua posição de que a pedagogia tem sua significação epistemológica assumindo-se como ciência da prática social da educação.

Diferentemente das demais ciências da educação, a pedagogia é ciência da prática. (...) Ela não se constrói como discurso sobre a educação, mas a partir da prática dos educadores tomada como referência para a construção de saberes, no confronto com os saberes teóricos. (...) O objeto/problema da pedagogia é a educação enquanto prática social. Daí seu caráter específico que a diferencia das demais (ciências da educação), que é o de uma ciência prática - parte da prática e a ela se dirige. A problemática educativa e sua superação constituem o ponto central de referência para a investigação.

Ainda desenvolvendo o assunto, Pimenta recorre a Jean Houssaye que nega que a pedagogia possa ter sua origem nas ciências da educação, "porque estas não podem fornecer a prática, indispensável à elaboração pedagógica. (...) Freqüentando o curso de ciências da educação, os futuros práticos poderão adquirir saberes sobre a educação e sobre a pedagogia, mas não estarão aptos a falarem sobre saberes pedagógicos" (Houssaye 1995).

Defendemos, pois, a criação do curso de pedagogia, um curso que oferece formação teórica, científica e técnica para interessados no aprofundamento da teoria e da pesquisa pedagógica e no exercício de atividades pedagógicas específicas (planejamento de políticas educacionais, gestão do sistema de ensino e das escolas, assistência pedagó- 
gico-didática a professores e alunos, avaliação educacional, pedagogia empresarial, animação cultural, produção e comunicação nas mídias etc.). ${ }^{13}$

A existência desse curso tem como suporte algumas premissas:

- $\quad$ O fenômeno educativo sujeita-se à pluralidade de abordagens, à medida que a educação é objeto de várias ciências que o abordam de seu enfoque específico. O estudo da educação tem um caráter de multirreferencialidade - abarca tanto modalidades educativas escolares quanto extra-escolares, como os movimentos sociais, a educação ambiental, educação comunitária, educação de grupos sociais marginalizados e de minorias sociais. Não é que se descarte o fato de que a educação escolar seja, ainda hoje, a forma histórica predominante de prática educativa. Mas, mesmo em benefício de uma educação escolar mais aberta e mais articulada com outras instâncias educativas fora de seu marco próprio, a idéia é a de que o educativo não se restrinja ao escolar, uma vez que abrange as relações mais amplas entre o indivíduo e o meio humano, social, físico, ecológico, cultural, econômico.

- Se, por um lado, a compreensão ampliada da educação fortalece as ciências da educação pelo fato de a pedagogia não ser a única área científica que tem a educação como objeto de estudo, por outro, não descaracteriza a especificidade da pedagogia como uma das ciências da educação. Com efeito, cada uma das chamadas ciências da educação (sociologia da educação, psicologia da educação, lingüística aplicada à educação, economia da educação etc.) aborda o fenômeno educativo da perspectiva de seus próprios conceitos e métodos de investigação, ao passo que a pedagogia se distingue por estudar o fenômeno educativo em sua totalidade, inclusive para integrar os enfoques parciais daquelas ciências em função de uma aproximação global e intencionalmente dirigida aos problemas educativos.

- Um currículo de pedagogia, além de contemplar como objeto de investigação a pluralidade das práticas educativas, concentra sua temática investigativa nos saberes pedagógicos, com a contribuição das ciências da educação, na forma de inter-relação entre os saberes científicos. Ou seja, assume-se o entendimento de pedagogia como ciência da prática social da educação para daí se definirem saberes pedagógicos (cf. Pimenta 1997). A integração de 
conhecimentos pela inter-relação entre saberes decorre não apenas da pluralidade que caracteriza o fenômeno educativo, mas também de uma tendência irrefreável das ciências no mundo contemporâneo buscarem a integração entre os saberes, sem perder de vista a especificidade disciplinar.

O currículo terá uma forte orientação para a pesquisa, seja como prática acadêmica, seja como atitude. Ressaltem-se, aí, os vínculos entre o ensino e a pesquisa, a pesquisa como forma básica de construção do saber, em confronto, em questionamento, com os saberes já estabelecidos e como instrumento para desenvolvimento das competências do pensar.

- Tal concepção de pedagogia deveria transpassar toda a formação pedagógica nos cursos de formação de professores, da educação infantil ao Ensino Médio.

\section{Os cursos de formação de professores da educação básica: A defesa de um local institucional específico para formar professores}

A atividade docente vem se modificando em decorrência de transformações nas concepções de escola e nas formas de construção do saber, resultando na necessidade de se repensar a intervenção pedagógico-didática na prática escolar. Um dos aspectos cruciais dessas transformações, os quais têm se evidenciado em avaliações educacionais como o Saresp (1996, 1997 e 1998), é o investimento na qualidade da formação dos docentes e no aperfeiçoamento das condições de trabalho nas escolas, para que estas favoreçam a construção coletiva de projetos pedagógicos capazes de alterar os quadros de reprovação, retenção e da qualidade social e humana dos resultados da escolarização.

Tem sido unânime a insatisfação de gestores, pesquisadores e professores com as formas convencionais de se formar professores em nosso país. Realizados em dois níveis de ensino - Médio e Superior -, os atuais cursos não dão conta de preparar o professor com a qualidade que se exige hoje desse profissional. No nível médio, realiza-se a formação dos professores das quatro séries iniciais do Ensino Fundamental e, em alguns casos, a formação dos professores para a educação infantil. Às vezes esses profissionais são formados no nível superior (nos atualmente chamados cursos de pedagogia). Os professores para as sé- 
ries seguintes do Ensino Fundamental e para o Ensino Médio são formados no nível superior, recorrendo ao velho esquema dos cursos de bacharelado e licenciatura. Conforme mencionamos anteriormente, essas modalidades de formação já demonstraram historicamente seu esgotamento (em nosso país e em vários outros). ${ }^{14}$ Dentro desse quadro, o aprimoramento do processo de formação de professores requer muita ousadia e criatividade para que se construam novos e mais promissores modelos educacionais necessários à urgente e fundamental tarefa de melhoria da qualidade do ensino no país.

A LDB no 9.394/96, em seu art. 62, estabelece como regra que a formação dos docentes para a educação fundamental e para a educação infantil far-se-á em nível superior. A elevação da formação docente em nível superior, reivindicação antiga dos educadores em nosso país e já consolidada em grande parte dos países desenvolvidos, fica assim contemplada. No mesmo art. 62, no entanto, admite-se como formação mínima para as séries iniciais e para a educação infantil, "a oferecida em nível médio, na modalidade Normal". Nesse caso, em nada superaria a situação historicamente vivida em relação à habilitação específica do magistério. Por outro lado, as disposições transitórias da referida lei (Título IX, art. 87, parágrafo 4ำ determinam que, até o final da Década da Educação (2007), "somente serão admitidos professores habilitados em nível superior ou formados por treinamento em serviço". Incorpora-se, dessa forma, avanço mundialmente consolidado de formação docente em nível superior. A LDB institui, também, a possibilidade de que a formação dos professores para todos os níveis de escolaridade ocorra nos Institutos Superiores de Educação, não necessariamente universitários. A partir de então, aceleram-se algumas alterações no cenário da formação de professores, o que aponta para a urgência de um posicionamento quanto à formação dos professores como profissionais da educação. As inovações curriculares - interdisciplinaridade, sala-ambiente, ciclos de aprendizagem e outras - requerem dos professores novas exigências de atuação profissional e, em conseqüência, novos saberes pedagógicos, que nem sempre tiveram lugar em sua formação.

\section{Que professor queremos formar?}

Na sociedade contemporânea, as rápidas transformações no mundo do trabalho, o avanço tecnológico configurando a sociedade virtual e 
os meios de informação e comunicação incidem com bastante força na escola, aumentando os desafios para torná-la uma conquista democrática efetiva. Não é tarefa simples nem para poucos. Transformar as escolas em suas práticas e culturas tradicionais e burocráticas - as quais, por meio da retenção e da evasão, acentuam a exclusão social - em escolas que eduquem as crianças e os jovens, propiciando-lhes um desenvolvimento cultural, científico e tecnológico que Ihes assegure condições para fazerem frente às exigências do mundo contemporâneo, exige esforço do coletivo da escola - professores, funcionários, diretores e pais de alunos -, dos sindicatos, dos governantes e de outros grupos sociais organizados.

Não se ignora que esse desafio precisa ser prioritariamente enfrentado no campo das políticas públicas. Todavia, não é menos certo que os professores são profissionais essenciais na construção dessa nova escola. Entendendo que a democratização do ensino passa pela sua formação, sua valorização profissional, suas condições de trabalho, pesquisas e experiências inovadoras têm apontado para a importância do investimento no desenvolvimento profissional dos professores. O desenvolvimento profissional envolve formação inicial e contínua articuladas a um processo de valorização identitária e profissional dos professores. Identidade que é epistemológica, ou seja, que reconhece a docência como um campo de conhecimentos específicos configurados em quatro grandes conjuntos, a saber: conteúdos das diversas áreas do saber e do ensino, ou seja, das ciências humanas e naturais, da cultura e das artes; conteúdos didático-pedagógicos (diretamente relacionados ao campo da prática profissional); conteúdos relacionados a saberes pedagógicos mais amplos (do campo teórico da prática educacional) e conteúdos ligados à explicitação do sentido da existência humana (individual, sensibilidade pessoal e social). ${ }^{15} \mathrm{E}$ identidade que é profissional. Ou seja, a docência constituiu um campo específico de intervenção profissional na prática social - não é qualquer um que pode ser professor.

Uma visão progressista de desenvolvimento profissional exclui uma concepção de formação baseada na racionalidade técnica (em que os professores são considerados mero executores de decisões alheias) e assume a perspectiva de considerá-los em sua capacidade de decidir e de rever suas práticas e as teorias que as informam, pelo confronto de suas ações cotidianas com as produções teóricas, pela pesquisa da prática e a produção de novos conhecimentos para a teoria e a prática de ensinar. Considera, assim, que as transformações das práticas docentes só se efetivam na medida em que o professor amplia sua consciência so- 
bre a própria prática, a da sala de aula e a da escola como um todo, o que pressupõe conhecimentos teóricos e críticos sobre a realidade. ${ }^{16}$ Dessa forma, os professores contribuem para a criação, o desenvolvimento e a transformação nos processos de gestão, nos currículos, na dinâmica organizacional, nos projetos educacionais e em outras formas de trabalho pedagógico. Por esse raciocínio, reformas gestadas nas instituições, sem tomar os professores como parceiros/autores, não transformam a escola na direção da qualidade social. Em conseqüência, valorizar o trabalho docente significa dotar os professores de perspectivas de análise que os ajudem a compreender os contextos históricos, sociais, culturais, organizacionais nos quais se dá sua atividade docente.

Nas últimas décadas assistimos a uma ampliação das oportunidades de acesso à escola, em que pesem as diferenças entre as regiões. Poder-se-ia concluir que o país tem uma escola que realizou a inclusão social de todos? Não nos parece, pois a essa ampliação quantitativa, em grande parte resultante da reivindicação dos educadores e da população, não correspondeu a melhoria das condições de trabalho, de jornada, de organização e funcionamento, de formação e valorização do professor, fatores essenciais para a qualidade do ensino. Sem isso, a escola quantitativamente ampliada permanece excludente. Ao desenvolver um ensino aligeirado, impossibilita a inserção social de crianças e jovens de classes sociais mais pobres em igualdade de condições com aqueles dos segmentos economicamente favorecidos, acentuando a exclusão social.

Uma escola que inclua, ou seja, que eduque todas as crianças e jovens, com qualidade, superando os efeitos perversos das retenções e evasões, propiciando-Ihes um desenvolvimento cultural que lhes assegure condições para fazerem frente às exigências do mundo contemporâneo, precisa de condições para que, com base na análise e na valorização das práticas existentes que já apontam para formas de inclusão, se criem novas práticas: de aula, de gestão, de trabalho dos professores e dos alunos, formas coletivas, currículos interdisciplinares, uma escola rica de material e de experiências, como espaço de formação contínua, e tantas outras. Por sua vez, os professores contribuem com seus saberes específicos, seus valores, suas competências, nessa complexa empreitada, para o que se requer condições salariais e de trabalho, formação inicial de qualidade e espaços de formação contínua.

Dada a natureza do trabalho docente, que é ensinar como contribuição ao processo de humanização dos alunos historicamente situados, espera-se dos processos de formação que desenvolvam conhecimentos 
e habilidades, competências, atitudes e valores que possibilitem aos professores ir construindo seus saberes-fazeres docentes a partir das necessidades e desafios que o ensino como prática social lhes coloca no cotidiano. Espera-se, pois, que mobilizem os conhecimentos da teoria da educação e do ensino, das áreas do conhecimento necessárias à compreensão do ensino como realidade social, e que desenvolvam neles a capacidade de investigar a própria atividade (a experiência) para, a partir dela, constituírem e transformarem os seus saberes-fazeres docentes, num processo contínuo de construção de suas identidades como professores. ${ }^{17}$

Em síntese, dizemos que o professor é um profissional do humano que: ajuda o desenvolvimento pessoal/intersubjetivo do aluno; um facilitador do acesso do aluno ao conhecimento (informador informado); um ser de cultura que domina de forma profunda sua área de especialidade (científica e pedagógica/educacional) e seus aportes para compreender o mundo; um analista crítico da sociedade, portanto, que nela intervém com sua atividade profissional; um membro de uma comunidade de profissionais, portanto, científica (que produz conhecimento sobre sua área) e social. ${ }^{18}$

Esse profissional deve ser formado nas universidades, que é o lugar da produção social do conhecimento, da circulação da produção cultural em diferentes áreas do saber e do permanente exercício da crítica histórico-social.

\section{Centro de Formação, Pesquisa e Desenvolvimento Profissional de Professores (CPD): Uma proposta}

Tendo argumentado sobre a especificidade da pedagogia e da formação de pedagogos stricto sensu, não identificados com professores, e explicitado a importância da formação destes, ampliada para o conceito de desenvolvimento profissional, passamos a propor a nossa visão da formação de professores. Um ponto de vista radical sobre essa questão leva ao enfrentamento do desafio da definição dos locais institucionais para a formação desses profissionais e de orientações explícitas sobre a organização curricular, assegurando um suporte legal de marcos institucionais e curriculares nacionais. Dessa forma, acreditamos que são necessárias decisões por parte das instâncias normativas do sistema educacional que considerem o tratamento global da questão, reven- 
do os locais institucionais de formação - de modo a superar os evidentes (e consensuais) problemas e impasses que têm marcado a formação de professores tanto nas faculdades de educação como nos institutos/ departamentos/cursos das universidades - e estabelecendo orientações mais específicas para a organização curricular dos cursos, contemplando a formação pedagógica e a específica no âmbito dos saberes disciplinares.

Por isso, sugerimos que a Faculdade (Centro) de Educação incorpore em sua estrutura, ao lado do curso de pedagogia, o Centro de Formação, Pesquisa e Desenvolvimento Profissional de Professores - CFPD - que terá quatro objetivos:

a) formação e preparação profissional de professores para atuar na educação básica: educação infantil, Ensino Fundamental ( $1^{\underline{a}}$ a $8^{\text {a }}$ série) e Ensino Médio;

b) desenvolver, em colaboração com outras instituições (Estado, sindicatos etc.), a formação contínua e o desenvolvimento profissional dos professores;

c) realizar pesquisas na área de formação e desenvolvimento profissional de professores;

d) preparação profissional de professores que atuam no Ensino Superior.

Esses objetivos configuram um projeto pedagógico próprio para a formação e o desenvolvimento profissional de professores.

\section{Por que em um centro específico e nas faculdades de educação?}

A inserção na estrutura das faculdades (centros) de educação do CFPD pretende ser uma virada de rumo na formação de professores. É preciso uma mudança radical nas formas institucionais e curriculares de formação de professores, superando o atual esquema do bacharelado e da licenciatura, que não responde mais às necessidades prementes de qualificação profissional para um tempo novo. Centrar a formação de professores numa instituição modelar como têm sido as faculdades de educação e atribuir-Ihe a responsabilidade de concatenar, no âmbito das universidades, as políticas e planos de formação de professores, em estreita articulação com os institutos, faculdades ou departamentos das áre- 
as especificas, pode ser garantia não apenas de melhoria da qualidade de formação, mas da profissionalidade do professorado, de modo que se configurem sua identidade e seu estatuto profissional.

As faculdades de educação têm sido, ao longo destas décadas, local da produção do conhecimento sobre educação e ensino que, na maioria das vezes, tem sido ignorado pelos institutos/departamentos/cursos específicos. No entanto, os problemas encontrados nas atuais faculdades de educação e que exigem destas uma reformulação, referem-se, a nosso ver, de um lado, à ambigüidade nelas presente quanto ao tratamento das "ciências da educação" dissociadas das questões referentes à profissionalidade docente e, de outro, à ambigüidade dos cursos de pedagogia que, ao se restringirem à formação dos professores das séries iniciais do Ensino Fundamental ou à formação técnico-burocrática dos "especialistas", conforme tratamos no item anterior, perderam sua especificidade de produção do conhecimento na área educacional. Há que se considerar, ainda, a desigualdade de importância entre os saberes constitutivos da docência na formação dos professores, privilegiando aqueles relacionados às competências didático-pedagógicas do ensino (metodologias e práticas de ensinar), considerados de modo fragmentado e dissociados das áreas específicas e apenas disciplinares e os relacionados aos saberes pedagógicos mais amplos. Estes, via de regra, desarticulados daqueles. Por sua vez, os institutos/departamentos/cursos, via de regra, desenvolvem os conteúdos específicos das áreas, ignorando a docência como atividade profissional de seus egressos e, portanto, ignorando os conhecimentos pedagógicos/educacionais necessários à mediação profissional dos especialistas em atividades de ensinar.

Considerem-se, também, as enormes dificuldades que ambos, faculdades de educação e institutos, encontram para valorizar e efetivar a pesquisa sobre ensino e docência nas respectivas instituições, por tratarem de área tradicionalmente menos prestigiada na comunidade científica nacional e internacional. Já há um consenso em algumas universidades, faculdades de educação, institutos, comunidades científicas e nas áreas de ensino e entidades de educadores, de que a formação de professores precisa se constituir em um projeto pedagógico próprio, articulado entre diferentes instâncias de formação de professor. O que favoreceria, inclusive, a valorização dessa área na comunidade científica, em termos de verbas para projetos, pesquisas, experiências inovadoras e até articulação entre as instâncias de formação inicial e os locais sociais de exercício da profissão docente. 
Um centro específico de formação, pesquisa e desenvolvimento profissional de professores possibilitaria a superação da hoje dicotômica visão da docência. O exercício profissional em um dado nível do ensino configura uma dimensão de uma totalidade que é a docência. Em qualquer nível (e local: escolar e não-escolar) em que ocorra, a docência configura uma visão de conjunto, de totalidade (à semelhança do médico que, em qualquer campo de ação que atue, é médico!) e um processo contínuo. Os atuais cursos de formação não lidam com essa categoria. Os professores que atuam nas séries finais do Ensino Fundamental ignoram a problemática e as questões essenciais da docência nos demais segmentos, o que traz problemas insuperáveis nos resultados do ensino e do processo formativo, pois seus profissionais operam a docência como um conjunto de "gavetas fragmentadas e justapostas", negando a característica de complexidade do fenômeno ensino.

\section{Em que o CPPD avança na discussão sobre a formação de professores}

A institucionalização do CFPD possibilita a incorporação dos princípios que os educadores construíram ao longo dos últimos anos (explicitados nas pesquisas, nas experiências, na vivência profissional, nos movimento de educadores pela formação profissional e em diversos fóruns de debates):

- $\quad$ introduz o conceito de desenvolvimento profissional, superando uma visão dicotômica da formação inicial e da formação contínua;

- toma a pesquisa como componente essencial da/na formação. Incorpora as recentes contribuições da formação do professor/pesquisador baseadas na epistemologia da prática, propondo percursos de formação teórico/práticos, nos quais a pesquisa é tanto formação do docente como este também se forma como pesquisador $^{19}$ (ver o item IV.c. experiência e prática profissionais: uma formação integrada, Documento Norteador);

- a formação é especialmente voltada para a profissionalidade docente e para a construção da identidade do professor. Experiências bem-sucedidas (especialmente as realizadas em alguns cursos de pedagogia) mostram que os cursos que se voltaram para tematizar a formação e o exercício da docência como objeto de formação e pesquisa podem se constituir em espaços mais férteis na produ- 
ção de conhecimento e mais compromissados com a prática social da docência;

- $\quad$ investe em sólida formação teórica nos quatro campos que constituem os saberes da docência;

- considera a prática social concreta da educação como objeto de reflexão/formação;

- $\quad$ considera a visão de totalidade do processo escolar/educacional;

- constitui um projeto pedagógico coletivo e interdisciplinar para a formação, desenvolvendo em igualdade de importância os quatro campos dos saberes da docência (conteúdos formativos, conforme o Documento Norteador);

- $\quad$ eleva a formação de todos os professores ao Ensino Superior;

valoriza a atividade intelectual, crítica e reflexiva da docência como elemento de melhoria da qualidade da formação profissional dos professores;

- $\quad$ apresenta currículo e percursos de formação abertos, permitindo um vai-e-vem entre as várias instituições da universidade que desenvolvem conteúdos formativos para a docência.

- O CFPD assegurará ainda:

um sólido curso de graduação em que estará presente a unidade ensino/pesquisa/extensão, elevando o estatuto da formação de professores e assegurando a valorização profissional, situando todos os professores no mesmo nível de formação e salários;

- a ampliação da responsabilidade das faculdades de educação e o reconhecimento da importância do seu papel na formação de professores, assim como a redefinição das responsabilidades dos institutos/faculdades/departamentos das áreas do conhecimento, na formação dos professores dentro de um projeto mais explícito de formação profissional do professorado;

- a eleição da prática como elemento integrante de todo o percurso de formação, constituindo um princípio epistemológico da formação (e não um apêndice);

- $\quad$ a incorporação de contribuições de experiências bem-sucedidas de formação em nosso país. 
A formação de professores para qualquer um dos níveis de ensino no CFPD estará assentada na compreensão de que a escolaridade constitui um processo contínuo e uma totalidade, superando a atual fragmentação. Além disso, possibilitará que os graduados complementem e ampliem sua formação para atuar em diferentes níveis de ensino.

Com base em diagnósticos de necessidades e demandas, o CFPD oferecerá programas para atendimento específico, por exemplo, na formação inicial para professores leigos, para a população indígena; desenvolvimento profissional de professores que já atuam nos sistemas escolares e outros. Tais programas poderão ser objeto de convênios com Secretarias de Educação, sindicatos etc. Por seu potencial formativo, integrarão o projeto pedagógico de formação inicial do CFPD.

\section{Formação teórico-prática articulada na formação inicial e contínua}

As investigações recentes sobre formação de professores apontam como questão essencial o fato de que os professores desempenham uma atividade teórico-prática. É difícil pensar na possibilidade de educar fora de uma situação concreta e de uma realidade definida. A profissão de professor precisa combinar sistematicamente elementos teóricos com situações práticas reais. Por essa razão, ao se pensar um currículo de formação, a ênfase na prática como atividade formadora aparece, à primeira vista, como exercício formativo para o futuro professor. Entretanto, em termos mais amplos, é um dos aspectos centrais na formação do professor, em razão do que traz conseqüências decisivas para a formação profissional.

Atualmente, em boa parte dos cursos de licenciatura, a aproximação do futuro professor à realidade escolar acontece após ele ter passado pela formação "teórica", tanto na disciplina especifica como nas disciplinas pedagógicas. O caminho deve ser outro. Desde o ingresso dos alunos no curso, é preciso integrar os conteúdos das disciplinas em situações da prática que coloquem problemas aos futuros professores e Ihes possibilitem experimentar soluções. Isso significa ter a prática, ao longo do curso, como referente direto para contrastar seus estudos e formar seus próprios conhecimentos e convicções a respeito. Ou seja, os alunos precisam conhecer o mais cedo possível os sujeitos e as situações com que irão trabalhar. Significa tomar a prática profissional como 
instância permanente e sistemática na aprendizagem do futuro professor e como referência para a organização curricular.

Significa, também, a articulação entre formação inicial e formação continuada. Por um lado, a formação inicial estaria estreitamente vinculada aos contextos de trabalho, possibilitando pensar as disciplinas com base no que pede a prática; cai por terra aquela idéia de que o estágio é aplicação da teoria. Por outro, a formação continuada, a par de ser feita na escola a partir dos saberes e experiências dos professores adquiridos na situação de trabalho, articula-se com a formação inicial, indo os professores à universidade para uma reflexão mais apurada sobre a prática. Em ambos os casos, estamos diante de modalidades de formação em que há interação entre as práticas formativas e os contextos de trabalho. Com isso, institui-se uma concepção de formação centrada na idéia de escola como unidade básica da mudança educativa, em que as escolas são consideradas "espaços institucionais para a inovação e a melhoria e, simultaneamente, como contextos privilegiados para a formação contínua de professores" (Escudero e Botia 1994).

\section{Sobre formar professores no curso de pedagogia}

A tendência predominante hoje no Brasil e expressa na LDB, de formação de professores para a educação infantil e as séries iniciais do Ensino Fundamental em nível superior, representa uma conquista dos educadores brasileiros, amplamente tematizada nas Conferências Brasileiras de Educação (CBEs), a partir de 1981.

Desde então a formação desses professores no Ensino Superior tem sido experimentada em cursos de pedagogia. Alguns desses cursos implantaram propostas inovadoras de formação com importantes resultados sociais e profissionais, principalmente quando sua clientela é composta de professores que já atuam nos sistemas de ensino. Tem sido freqüente nesses cursos tomar a prática docente como objeto de formação teórico-prática, contribuindo para ampliar o conhecimento no campo da formação de professores. Outros cursos mantiveram a formação dos professores de $1^{\underline{a}}$ a $4^{a}$ série apenas como uma habilitação ao lado de outras. Estes, à guisa de pretenderem formar especialistas e professores, acabam por não dar conta de uma formação de qualidade em nenhum caso, conforme procuramos demonstrar. Outros, ainda, muito poucos, for- 
mam pedagogos para a educação escolar (em geral, coordenadores pedagógicos) e, aqui e ali, preparam os pedagogos para atuar em outros espaços sociais da educação, como os movimentos sociais, a educação de jovens e adultos, os meios de comunicação etc. Esses profissionais, em grau maior ou menor, desenvolvem a pesquisa em áreas diversas da prática educativa.

Dados de pesquisa têm mostrado que, no primeiro caso, os cursos de pedagogia se transformaram em ótimos cursos de formação de professores. Entendemos que essas experiências bem-sucedidas não apenas devem continuar, como devem ser apoiadas financeira e institucionalmente, pelos setores públicos e governamentais, pelas agências de fomento e de financiamento de pesquisas para que sistematizem o conhecimento produzido com base na experiência praticada e desenvolvam mais pesquisas sobre formação de professores, fortalecendo assim teórica, científica e politicamente a área. Há razões suficientes para afirmar que esses cursos, do ponto de vista curricular e metodológico, mobilizam os saberes pedagógicos e os saberes das áreas específicas para, na confluência com a experiência dos professores-alunos, contribuírem à formação teórico-prática dos mesmos. São, pois, excelentes cursos de formação de professores, embora, a nosso ver, não sejam cursos de formação de pedagogos stricto sensu.

Por outro lado, do mesmo modo que rejeitamos a redução do curso de pedagogia à formação de professores para a educação infantil e as séries iniciais do Ensino Fundamental, não nos pareceu oportuna a designação de Escola Normal Superior dada a esses cursos na legislação mais recente do Conselho Nacional de Educação. A argumentação que desenvolvemos até aqui acentua nossa posição contrária à extinção do curso de pedagogia, como também contrária à autonomização de uma Escola Normal Superior. A nosso ver, a institucionalização da Escola Normal Superior significa a reedição da antiga Escola Normal cuja concepção está ultrapassada. A legislação recente do CNE não só não acrescenta nada de novo, como também não incorpora inovações e funções já bastante difundidas na produção de conhecimento na área, como a interligação entre formação inicial e continuada, o desenvolvimento profissional dos professores, a pesquisa-ação, a unidade do processo formativo dos professores de todos os níveis e modalidades de ensino. Desse modo, é lastimável que - CNE esteja legislando aos pedaços, levando à fragmentação da legislação e dos próprios cursos, desconsiderando a idéia de um sistema integrado e articulado de formação dos profissionais da educação e a rica investigação teórica produzida na universidade e nas escolas. 


\section{Concluindo}

Entendendo que a análise crítica da realidade existente é imprescindível para sua transformação, pretendemos, com o presente artigo, colaborar para essa análise, oferecendo perspectivas e alternativas até então pouco exploradas na literatura sobre os cursos de pedagogia e de formação de professores. Em decorrência, entendemos que "modelos únicos" não apenas não respondem à diversidade e à desigualdade de nosso país, como representam autoritarismos que ferem a capacidade e a competência dos educadores brasileiros de apresentarem propostas efetivamente compromissadas com a qualidade social da educação para nosso país. Assim, este artigo traz contribuições para o alargamento da consciência dos educadores, de modo que em suas práticas institucionais concretamente situadas gestem propostas que confiram à pedagogia e à formação de professores o estatuto de importância científica, social e cultural, num país em que é comum serem jogadas fora conquistas duramente conseguidas na construção da democracia escolar e educacional.

\section{Notas}

1. As idéias aqui expostas são desdobramentos da declaração de voto em separado firmada pelos autores e anexada ao Documento Norteador para a Elaboração das Diretrizes Curriculares para os Cursos de Formação de Professores, elaborado pelo Grupo de Trabalho designado pela SESu/MEC, através da Portaria no 808, de 8/6/1999, e encaminhado em 16/9/1999. O GT foi constituído pelos professores-doutores: Antônio Joaquim Severino (coordenador), Helena Costa Lopes de Freitas, José Carlos Libâneo, Luís Carlos de Menezes e Selma Garrido Pimenta. Na declaração de voto é destacada a necessidade e a relevância de se enfrentar uma das questões cruciais da educação nacional, que é a organização de um sistema nacional de formação dos profissionais da educação, conforme o Título VI da LDB no 9.394/96, incluindo, portanto, a formação de professores, de pedagogos especialistas e de profissionais para outras tarefas sociais da educação, uma vez que o Documento Norteador refere-se tão-somente à formação de professores.

2. O reforço da expressão stricto sensu seria desnecessário já que pedagogia é, antes de tudo, um campo de conhecimentos cujo objeto é o fenômeno educativo e o curso que lhe corresponde refere-se, obviamente, a uma seqüência de estudos relacionada com esse objeto. Entretanto, está sendo uti- 
lizada aqui para se distinguir do curso de formação de professores para as séries iniciais, uma identificação longe de ter um suporte teórico-conceitual para avalizá-la.

3. Em publicação recente, Silva (1999) descreve e analisa o percurso do curso de pedagogia no Brasil, com base nas regulamentações e propostas de estrutura curricular, visando, justamente, estudar sua busca de identidade. Em publicação anterior, Brzezinski (1998) faz uma radiografia da formação de professores. Cf., também, Libâneo 1999 (2º edição). Em relação especificamente às licenciaturas, há vários trabalhos relevantes, entre outros, Castro (1974), Candau (1987), Bernardo (1989), Silva (1991), Freitas (1992), Lüdke (1994), Gatti (1998).

4. Silva (op. cit.) relata em seu livro conclusões do Congresso Estadual de Estudantes de Pedagogia, realizado em São Paulo em 1967, em que estes reivindicavam a exclusividade de exercício profissional para o licenciado em pedagogia em cargos e funções como orientador educacional, diretor de escola média, inspetor de Ensino Médio, técnico em educação, professor de recursos audiovisuais em educação, técnico de recursos audiovisuais em educação, pesquisador educacional, assistente técnico-pedagógico. Os estudantes recomendavam, também, a criação, em caráter efetivo, de cargos e funções para suprir, com os licenciados em pedagogia, necessidades educacionais da realidade brasileira, tais como: planejamento educacional, TV educativa, educação de adultos, formulação de uma filosofia da educação, reformulação de política educacional, educação de excepcionais, desenvolvimento de recursos humanos, atividades comunitárias, avaliação de desempenho em escolas e empresas, administração de pessoal, educação sanitária. Chegaram, inclusive, a recomendar a participação do pedagogo na formação, adaptação e aperfeiçoamento do funcionalismo público paulista.

5. As habilitações não se reduziam a essas oito, podendo ser criadas outras por iniciativa do CFE e dos próprios estabelecimentos. É interessante notar que as habilitações reclamadas pelos estudantes em 1967 (Cf. nota 5) foram incorporadas pelo relator no Parecer.

6. Cabe lembrar que algumas dessas habilitações já existiam no nível pós-médio, nos então Institutos de Educação, criados nos anos 30 .

7. Diferentes posicionamentos de pesquisadores em relação a essas críticas e inclusive ao papel dos pedagogos já se faziam sentir ao longo dos anos 70 e 80. À época em que discutia a identidade do curso de pedagogia e do profissional pedagogo, foram produzidas no programa de pós-graduação da PUCSP três teses sobre os especialistas de educação. Tais teses, posteriormente transformadas em livro (Silva Jr. 1985, Pimenta 1988, Paro 1988), deram (e ainda dão) suporte à atuação profissional dos pedagogos, ao recolocarem a prática da coordenação, da administração e da supervisão pedagógicas diante das novas demandas sociais, com base na crítica à tradição desses campos. Esses autores não endossaram a licenciatura na pedagogia, critica- 
ram a fragmentação das habilitações, mas propuseram a redefinição do curso de pedagogia e do pedagogo na escola e no sistema de ensino.

8. Algumas dessas questões são analisadas por Silva (op. cit.). Segundo ela, a variedade de especializações do curso de pedagogia decorrente de pretensões demasiadamente ambiciosas dos legisladores, resultou num "inchaço" do currículo, levando a duas ordens de dificuldades: primeira, a de atender simultaneamente às necessidades de formação de docentes e não-docentes; segunda, a de dar as condições de oferta de numerosas disciplinas para as várias habilitações e as múltiplas práticas de ensino. A situação se agrava, segundo a autora, à medida que, além da formação do professor para o ensino normal e dos especialistas, o Parecer assegura ainda o direito ao magistério nas séries iniciais do $1^{\circ}$ grau. "Adicionar às demais incumbências do curso de pedagogia a formação, também, desses profissionais, é superestimar as possibilidades do curso e/ou desconhecer as necessidades de formação desses docentes." Conclui a autora que um "inchaço" de tais proporções leva inevitavelmente à desqualificação de qualquer curso.

9. É necessário registrar que a trajetória do movimento pela reformulação dos cursos de formação do educador não manteve sempre a posição de minimizar o caráter teórico da pedagogia. Nos anos 1983-89, a pedagogia foi assumida como uma licenciatura destinada à formação de docentes para as disciplinas pedagógicas do $2^{\circ}$ grau e à formação de especialistas "de forma integrada", possibilitando uma ação conjunta desses profissionais na escola. Admitia-se, também, a criação de áreas de concentração em docência para as séries iniciais do $1^{\circ}$ grau, educação pré-escolar, educação de adultos, educação comunitária etc. Mas, especialmente, afirmava-se em 1986: "O curso de pedagogia tem uma destinação prática: formar profissionais da educação. (...) O curso de pedagogia tem também uma função teórica, não menos importante, de transmissão, crítica e construção de conhecimento sobre a ciência da educação". Mais tarde é que vai se firmando a idéia de identificar o curso de pedagogia com a formação de professores, reiterando a famosa tese de Valnir Chagas na sua Indicação n 70/76, de "habilitar o especialista no professor". Mostraremos, mais adiante, como esse entendimento acabou por tornar-se bastante limitado e empobrecedor da formação.

10. No Parecer 252/69, uma frase do relator revela uma das ambigüidades da concepção de curso de pedagogia que, segundo ele, "outra coisa não é senão o desenvolvimento em anos do que se estuda em meses para a licença comum do magistério". Da lógica desse raciocínio, depreende-se que o curso de pedagogia deveria ser mais do que uma licenciatura, ou seja, seria um curso de estudos sistemáticos da educação para formar seja professores do curso normal seja especialistas de educação. Não preponderantemente para formar o professor das séries iniciais do Ensino Fundamental, ou seja, uma licenciatura.

11. Libâneo, no livro Pedagogia e pedagogos, para quê? (1998, pp. 38-43, 91-95, 97-127), tenta refazer detalhadamente esse percurso da história do curso de 
pedagogia e de sua descaracterização como área específica de conhecimento e como campo de exercício profissional.

12. Ao explicitar a identidade profissional do pedagogo, escreve Carvalho (1996), ex-diretora da Faculdade de Educação da USP: "O ensino e a pesquisa (...) são os objetivos fundamentais de nossa faculdade. (...) Nós temos que ser realmente técnicos em Educação e técnicos na pesquisa em Educação. Técnico em um sentido amplo, sem a conotação pejorativa que este termo adquiriu nos anos 80 . Técnico (...) no sentido de conhecimento específico de ponta. (...) O curso, na minha opinião, deveria proporcionar aos seus alunos esta dupla visão, esta dupla formação. A escolha em ser um pesquisador ou um profissional da educação deveria ser do aluno no final do curso. Durante os 4 anos ele deveria ser preparado para as duas funções".

13. Há quem argumente que o curso de pedagogia para formar especialistas e cientistas da educação separa a teoria da prática, a teoria educacional da docência, o trabalho pedagógico do conteúdo. Do nosso lado, argumentamos que a pedagogia, como área específica de conhecimento, tem seus próprios conteúdos, formas e métodos. Os conteúdos da pedagogia (ou do trabalho pedagógico) não são os conteúdos das matérias. Quem entende assim está fazendo uma identificação descabida entre pedagogia e metodologia, trabaIho pedagógico e trabalho metodológico, como se fossem sinônimos. Ora, é evidente que a pedagogia, como campo científico, tem seu conteúdo próprio, suas formas conexas ao conteúdo e aos métodos, por mais que tais conteúdo e métodos tenham origem em boa parte das demais ciências da educação. Mas isso não constitui nenhum problema epistemológico, pois não se trata de uma exclusividade da pedagogia. Dificilmente uma ciência prescindirá do campo conceitual e de práticas metodológicas de outras. Sobre a relação teoria e prática, nossa proposta tem como suporte a unidade teoria e prática, ou seja, todas as disciplinas estarão referidas à prática e vice-versa, além de se prever o estágio específico onde couber. Gostaríamos, além disso, de levantar a suspeita de que em muitos casos a experiência de sala de aula não precisa ser salvo-conduto para o exercício profissional do pedagogo. Os objetos de estudo da pedagogia escolar, por exemplo, são a escola e o ensino. É óbvio que não se pode dispensar o futuro pedagogo do estágio na escola e na sala de aula, para aproximar-se da realidade. Nem por isso ele precisa ser obrigatoriamente professor, nem desempenhar estágio de ensino como professor. É claro que o objeto final a ser conhecido pelo pedagogo escolar é o ensino, mas isso não exclui o entendimento de que um diretor de escola, um coordenador pedagógico possuem também seu objeto imediato, no caso, a administração e a gestão da escola e a coordenação e a assistência pedagógico-didática.

14. França, Espanha, Portugal, Inglaterra, Canadá e Estados Unidos, dentre outros, têm considerado os professores como atores centrais na formulação e no desenvolvimento de inovações que objetivam um ensino de qualidade social, no qual a disseminação do conhecimento e de elementos substanciais 
da cultura é fundamental. Constata-se também o tratamento indissociado, nessas políticas, da questão da formação e do desenvolvimento profissional dos docentes, envolvendo o Estado, as universidades, as escolas e os sindicatos/associações científicas, bem como políticas de valorização efetiva das condições de formação, de trabalho e valorização profissional dos professores, envolvendo carreira e salários.

15. Conforme explicitados no Documento Norteador para a Elaboração das Diretrizes Curriculares para os Cursos de Formação de Professores, 1999, item III (Conteúdos formativos a serem desenvolvidos).

16. Ver item IV (Do processo formativo) do Documento Norteador para a Elaboração das Diretrizes Curriculares para os Cursos de Formação de Professores, 1999.

17 Ver à propósito Pimenta 1997 e 1999.

18 A partir de colaborações de Isabel Alarcão, na $22^{\underline{a}}$ Reunião Anual da Anped. 1999.

19. Ver Garrido, Fusari, Moura e Pimenta 1998, pp. 48-49.

\section{Educational professional \\ upbringingi: Critical view and changing perspectives}

ABSTRACT: The article presents brief critical analysis of the historical of the formation of the education professionals in Brazil, clearing the ambiguities of the course of pedagogy from its creation to the present time, the trajectory of the courses of teachers' formation and the impact of the debates promoted in the institutions, entities, movements, around the subject. In the sequence, the text analyzes the nature and the identity of the pedagogy as an area of knowledge of the educational field and the subjects related to the professional exercise of pedagogues and teachers. It finally indicates suggestions of institutional organization and some possible trajectories of those professionals' formation that point for a change of the current picture.

\section{Bibliografia}

ANFOPE. Documentos Finais de Encontros. 1983-92.

BERNARDO, Maristela V.C. "O surgimento e a trajetória da formação do professor secundário nas universidades estaduais paulistas". In: BERNARDO, M.V.C. (org.). Formação do professor: Atualizando o debate. São Paulo: Educ, 1989. 
BRZEZINSKI, Iria. Pedagogia, pedagogos e formação de professores. Campinas: Papirus, 1996.

CANDAU, Vera M. (coord.). Novos rumos da licenciatura: Pesquisa. Brasília: Inep/PUC-RJ, 1987.

CARVALHO, Anna M.P. de. "Identidade profissional do pedagogo: Introduzindo o debate". Estudos e Documentos (FE-USP). São Paulo, v. 36, 1996.

CASTRO, Amélia D. de. "A licenciatura no Brasil". Revista de História (USP) $n^{\circ}$ 100. Set. 1974.

CHAGAS, Valnir. Formação do magistério: Novo sistema. São Paulo: Atlas, 1976.

ESCUDERO, Juan M. e BOTIA, Bolívar. "Inovação e formação centrada na escola. Uma perspectiva da realidade espanhola". In: AMIGUINHO, Abílio e CANÁRIO, Rui (orgs.). Escolas e mudança: O papel dos Centros de Formação. Lisboa: Educa, 1994.

FERRARI, Yoshie e PIMENTA, Selma G. (coords.). "Formação de professores: Que política queremos?". Documento do Fórum Estadual Paulista de Formação de Professores para as Séries Iniciais do Ensino Fundamental. São Paulo, dez. 1997.

FREITAS, Luís C. "Em direção a uma política para a formação de professores". Em Aberto nº 54, abr./jun. 1992.

GARRIDO, Elsa; FUSARI, Maria F.R ; MOURA, Manoel O. de, e PIMENTA, Selma G. Projeto USP-Ayres/FE-USP/Fapesp: A pesquisa colaborativa, a formação do professor reflexivo/investigativo e a construção coletiva de saberes e práticas pela equipe escolar. Anais do IX Endipe - Encontro Nacional de Didática e Prática de Ensino. Águas de Lindóia, vol. 1, 1998, pp. 48-49.

GATTI, Bernadete A. Formação de professores e carreira. Campinas: Autores Associados, 1997.

LIBÂNEO, José C. Pedagogia e pedagogos, para quê? São Paulo: Cortez, 1998.

"Que destino os educadores darão à pedagogia?". In: PIMENTA, Selma G. (coord.). Pedagogia, ciência da educação? São Paulo: Cortez, 1996.

. "Reestruturação da Faculdade de Educação da UFG - Apontamentos críticos sobre seu projeto curricular de formação de edu- 
cadores e sua estrutura organizacional". Cadernos da Educação nº 1 FE-UFG. Goiânia, 1994, pp. 35-43-49.

Adeus professor, adeus professora? Novas exigências educacionais e profissão docente. São Paulo: Cortez, 1998.

LÜDKE, Menga. "Avaliação institucional: Formação de docentes para o Ensino Fundamental e médio (As licenciaturas)". Cadernos CRUB nํ⒋ Brasília, set. 1994.

PARO, Vitor. Administração escolar. São Paulo: Cortez, 1988.

PIMENTA, Selma G. O pedagogo na escola pública. São Paulo: Loyola, 1988.

- "Panorama atual da didática no quadro das ciências da educação: Educação, pedagogia e didática”. In: PIMENTA, Selma G. (coord.). Pedagogia, ciência da educação? São Paulo: Cortez, 1996.

. "Para uma re-significação da didática: Ciências da educação, pedagogia e didática, uma revisão conceitual, uma síntese provisória". In: PIMENTA, Selma G. (org.). Didática e formação de professores: Percursos e perspectivas no Brasil e em Portugal. São Paulo: Cortez, 1997.

. "Prefácio". In: LIBÂNEO, José C. Pedagogia e pedagogos, para quê? São Paulo: Cortez, 1998.

. "Formação de professores: Saberes e identidade da docência". In: PIMENTA, S.G. (org.). Saberes pedagógicos e atividade docente. São Paulo: Cortez, 1999.

Relatório Final da Comissão Especial para desenvolvimento de estudos sobre a formação dos profissionais da Educação no Estado de São Paulo (Conselho Estadual de Educação/SP). Revista de Educação no 10. São Paulo: Apeoesp, abr. 1999. (Membros da comissão: OLIVEIRA, Cleiton (coord.); AMBROSETTI, Neusa; FERRARI, Yoshie; FREITAS, Helena; OLIVEIRA, Zilma; SANTOS FILHO, José; PIMENTA, Selma G.;WEY, Vera).

SEVERINO, Antônio J. "Minuta do documento norteador para elaboração das diretrizes curriculares dos cursos de licenciatura (Segunda versão)". Documento apresentado ao GT-Licenciaturas da SESuMEC, 1999. Não publicado.

SEVERINO, Antônio J. (coord.); FREITAS, Helena; LIBÂNEO, José C.; MENEZES, Luis C.; PIMENTA, Selma. Documento Norteador para 
a Elaboração das Diretrizes Curriculares para os Cursos de Formação de Professores. SESu/MEC, set. 1999.

SILVA, Carmem S.B. da. Curso de pedagogia no Brasil: História e identidade. Campinas: Autores Associados, 1999.

SILVA JR., Celestino A. Supervisão da educação: Do autoritarismo ingênuo à vontade coletiva. São Paulo: Loyola, 1985. 